\section{REFERENCES AND NOTES}

1. Behrman RE, Lees MH, Peterson EN, deLannoy CW, Seeds AE 1970 Distribution of the circulation in the normal and asphyxiated fetal primate. Am J Obstet Gynecol 108:956

2. Bucciarelli RL, Nelson RM, Egan EA II, Eitzman DV, Gessner IH 1977 Transient tricuspid insufficiency of the newborn: a form of myocardial dysfunction in stressed newborns. Pediatrics 59:330

3. Burnard ED, James LS 1961 Failure of the heart after undue asphyxia at birth. Pediatrics 28:545

4. Cabal LA, Devaskar U, Siassi B, Hodgman JE, Emmanouilides G 1980 Cardiogenic shock associated with perinatal asphyxia in preterm infants. $\mathrm{J}$ Pediatr 96:705

5. Cohn HE, Sacks EJ, Heymann MA, Rudolph AM 1976 Cardiovascular responses to hypoxemia and acidemia in fetal lambs. Am J Obstet Gynecol $120: 817$

6. Dawes GS, Mott JC, Shelley HJ 1959 The importance of cardiac glycogen for the maintenance of life in foetal lambs and new-born animals during anoxia. J Physiol 146:516

7. DeSa DJ 1979 Coronary arterial lesions and myocardial necrosis in stillbirths and infants. Arch Dis Child 54:918

8. Dock W 1946 The predilection of atherosclerosis for the coronary arteries. J Am Med Assoc 131:875

9. Donnelly WH, Bucciarelli RL, Nelson RM 1980 Ischemic papillary muscle necrosis in stressed newborn infants. J Pediatr 96:295

10. Finley JP, Howman-Giles RB, Gilday DL, Bloom KR, Rowe RD 1979 Transient myocardial ischaemia of the newborn infant demonstrated by thallium myocardial imaging. J Pediatr 94:263

11. Fisher DJ, Heymann MA, Rudolph AM 1980 Myocardial oxygen and carbohydrate consumption in fetal lambs in utero and adult sheep. Am J Physiol 238(Heart Circ Physiol 7):H399

12. Fisher DJ, Heymann MA, Rudolph AM 1981 Myocardial consumption of oxygen and carbohydrates in newborn sheep. Pediatr Res 15:843
13. Fisher DJ, Heymann MA, Rudolph AM 1982 Regional myocardial blood flow and oxygen delivery in fetal, newborn, and adult sheep. Am J Physiol 243(Heart Circ Physiol 12):H729

14. Gruenwald P 1949 Necrosis in the coronary arteries of newborn infants. Am Heart J 38:889

15. Lees MH 1980 Perinatal asphyxia and the myocardium. J Pediatr $96: 675$

16. Meschia G, Cotter JR, Breathnach CS, Barron DH 1965 The diffusability of oxygen across the sheep placenta. Q J Exp Physiol 50:466

17. Nelson RM, Bucciarelli RL, Eitzman DV, Egan EA II, Gessner IH 1978 Serum creatinine phosphokinase MB fraction in newborns with transient tricuspid insufficiency. N Engl J Med 298:146

18. Peeters LIH, Sheldon RF, Jones MD Jr, Makowski EL, Meschia G 1979 Blood flow to fetal organs as a function of arterial oxygen content. Am J Obstet Gynecol 135:637

19. Rowe RD, Hoffman I 1972 Transient myocardial ischaemia of the newborn infant: a form of severe cardiorespiratory distress in full-term infants. $\mathbf{J}$ Pediatr 81:243

20. Setzer E, Ermocilla R, Tonkin I, John E, Sansa M, Cassady G 1980 Papillary muscle necrosis in a neonatal autopsy population: incidence and associated clinical manifestations. J Pediatr 96:289

21. Tweed WA, Cote J, Wade JG, Gregory G, Mills A 1982 Preservation of fetal brain blood flow relative to other organs during hypovolemic hypotension. Pediatr Res 16:137

22. The authors wish to acknowledge with thanks the financial support of the Medical Research Council of Canada, the Manitoba Heart Foundation, and the Alberta Heritage Foundation for Medical Research, and the technical assistance of Mr. Wayne Pucci, Miss Maureen Cumming, and Mr. Ken Gregory, of the Anesthesia Research Laboratory, University of Manitoba, where this work was completed.

23. Address correspondence to J. M. Davies, M.D., Department of Anaesthesia, Foothills Hospital at the University of Calgary, 140329 Street N. W., Calgary, Alberta, Canada, T2N 2T9.

24. Received for publication January 6, 1984.

\title{
Glycosylated Hemoglobin and Plasma Protein in Newborns of Normal and Diabetic Women
}

\author{
MOHAMED M. ELSEWEIDY, HOSSAM E. FADEL, AND EDATHARA C. ABRAHAM ${ }^{(29)}$
}

Department of Cell and Molecular Biology [M.M.E., E.C.A.] and Department of Obstetrics and Gynecology [H.E.F.], Maternal-Fetal Medicine Section, Medical College of Georgia, Augusta, Georgia, USA

\section{Summary}

The glycosylated hemoglobin (glyco $\mathrm{Hb}$ ) and the glycoprotein of the plasma were determined using affinity chromatographic techniques in cord blood and maternal blood of normal (Group I), White's Class A diabetic (Group II), and insulin-dependent diabetic (Group III) mothers. The results revealed significant increase of glyco $\mathrm{Hb}(P<0.005)$ and glycoprotein $(P<0.005)$ in the newborns of Group III mothers in comparison to those of Group I. The glyco $\mathrm{Hb}$ of maternal blood in this group also showed significant increase $(P<0.005)$ while the increase in $\mathrm{Hb}$ $A_{1}$ and plasma glycoprotein were nonsignificant. All values for cord blood and maternal blood of White's Class A diabetics revealed no significant change from the normal group. We conclude that the fetuses of insulin-dependent diabetic mothers are hyperglycemic in utero.

\section{Abbreviations}

glyco $\mathbf{H b}$, glycosylated hemoglobin

HEPES, 4-(2-hydroxyethyl)-1-piperazineethanesulfonic acid IDDM, insulin-dependent diabetes mellitus
The heterogeneity of human $\mathrm{Hb}$ has been known for some time $(7,17)$. Several chromatographically minor Hbs can be separated from adult red cell lysates using cation exchange chromatographic techniques which were designated $\mathrm{A}_{\mathrm{Ia} 1}, \mathrm{~A}_{\mathrm{Ia} 2}, \mathrm{~A}_{\mathrm{Ib}}$, and $A_{I c}$ based on their order of elution with $A_{I c}$ being the major subfraction $(19,23) . \mathrm{Hb} A_{l c}$ is formed by the reaction of the $\beta$ chain amino terminus of $\mathrm{Hb} \mathrm{A}_{0}$ (major hemoglobin) with glucose whereas $\mathrm{Hb} \mathrm{A} \mathrm{A}_{\mathrm{Ia}}$ and $\mathrm{Hb} \mathrm{\textrm {A } _ { \mathrm { la } 2 }}$ are formed by reaction of fructose1,6-diphosphate and glucose-6-phosphate, respectively (9). Hb $\mathrm{A}_{\mathrm{lb}}$ is a glyco $\mathrm{Hb}$ whose identity is not known. However, other glycohemoglobins that are formed by glycosylation of the $\alpha$ chain amino terminus and $\epsilon$-amino groups of certain lysyl residues on both chains are not normally separated by cation exchange chromatographic technique (25). Glycosylation of Hb occurs by a nonenzymatic reaction that is continuous throughout the lifespan of the red blood cell (8). It follows that glyco $\mathrm{Hb}$ levels will reflect the time-averaged blood glucose level over a period of 812 weeks $(16,20)$. This has led to increasing interest of the clinicians in the study of the glyco Hb levels in relation to diabetes mellitus $(14,15)$. Levels of $\mathrm{Hb} \mathrm{A}_{1}\left(\mathrm{~A}_{\mathrm{Ia}+\mathrm{b}+\mathrm{c}}\right)$ are increased in diabetes mellitus depending upon the degree of metabolic control 
(3, 9). This elevation of $\mathrm{Hb} \mathrm{A}_{\mathrm{i}}$ was also reported in pregnant women with diabetes mellitus whether diet controlled or insulindependent diabetics $(11,24)$. Several minor Hbs, namely $F_{\mathrm{Ia}}$, $\mathrm{F}_{\mathrm{Ia} 2}, \mathrm{~F}_{\mathrm{Ib}}$, and $\mathrm{F}_{\mathrm{Ic}}$, were separated from cord blood red cell lysates using similar cation exchange chromatographic techniques (1, 2). $\mathrm{Hb} \mathrm{F}_{\mathrm{Ic}}$ contains $\gamma$ chains mostly acetylated, but it contains minor glycosylated $\mathrm{Hb}$ as well $(1,2)$. In a previous study, it has been shown that the level of $\mathrm{Hb} \mathrm{F}_{\mathrm{Ic}}$ is increased in newborns of diabetic mothers; however, it was not shown whether this increase was due to an increase in acetylated or glycosylated form of $\mathrm{Hb} \mathrm{F}_{\mathrm{lc}}(12)$.

The specific interaction of boronic acid ligands with 1,2-cisdiol compounds resulted in affinity chromatographic techniques for the separation of some glycoproteins (27). Affinity chromatographic methods utilizing $m$-aminophenylboronic acid immobilized on agarose have been recently introduced to quantitate total glyco $\mathrm{Hb}$ even in the presence of $\mathrm{Hb} \mathrm{F}$ and various abnormal hemoglobins $(4,5)$. This technique is particularly suited for the quantitation of glyco $\mathrm{Hb}$ in cord blood. The purpose of this study was to use the new technique to find out if there are any significant differences in the levels of the glycosylated products ( $\mathrm{Hb}$ and plasma proteins) between newborns of normal and diabetic mothers. This would give a more accurate indication of the time-averaged blood glucose levels in utero in these pregnancies.

\section{MATERIALS AND METHODS}

Subjects. Forty-eight pregnant women participated in this study. Informed consent was obtained from all patients. They were classified into three groups as follows: Group I, 20 normal women with a normal glucose screening test, i.e., a blood glucose value $<130 \mathrm{mg} / \mathrm{dl} 1 \mathrm{~h}$ after a 50-g glucose load (10); Group II, 20 women with an abnormal oral glucose tolerance test, i.e., White's Class A diabetics who did not require insulin therapy. Group III, eight women with IDDM of whom seven were Class $\mathrm{B}$, and one was Class $\mathrm{C}$. The management of the diabetic patients was according to the routine protocol in our institution (10).

Blood samples. Samples of blood $(5-7 \mathrm{ml})$ were collected from mothers at the time of their admission in labor and from the cord (3-4 ml) at delivery. Blood was collected into tubes containing EDTA and stored at $4^{\circ} \mathrm{C}$. After $24 \mathrm{~h}$, the red cells were separated from the plasma by centrifugation and washed three times with isotonic saline. Both the cells and the plasma were used immediately for glyco $\mathrm{Hb}$ and glycoprotein determinations.

Affinity chromatographic quantitation of glyco components. Microcolumns (Glyc-Affin system from Isolab, Inc., Akron, $\mathrm{OH}$ ) prepacked with the affinity gel ( $m$-aminophenylboronic acid immobilized on agarose), and supplied reagents of the same company, were used. The following procedures which were recommended by the manufacturer were followed precisely. For glyco $\mathrm{Hb}$ determination, a $50-\mu \mathrm{l}$ aliquot of the cells suspended in saline was lysed with $400 \mu \mathrm{l}$ of the sample preparation reagent and $100 \mu \mathrm{l}$ of the lysate were applied to the column and developed at $25^{\circ} \mathrm{C}$. The nonglyco $\mathrm{Hb}$ fraction was eluted first with the first fraction elution agent (Solution II) or 0.05 M HEPES buffer, adjusted to $\mathrm{pH} 8.5$ with $\mathrm{HCl}$ and containing $10 \mathrm{mM} \mathrm{MgCl}_{2}$ and $0.02 \%$ sodium azide. The glyco $\mathrm{Hb}$ fraction (bound to the gel) was eluted with the second fraction elution buffer or $100 \mathrm{mM}$ sorbitol. So every sample was fractionated into two fractions: glyco and nonglyco $\mathrm{Hb}$. The absorbance of each fraction was read at $415 \mathrm{~nm}$ in a Beckman spectrophotometer. The percentage of glyco $\mathrm{Hb}$ was calculated from the readings. For glycoprotein determination, $500 \mu \mathrm{l}$ of plasma were mixed with $500 \mu \mathrm{l}$ of first fraction elution agent. A $400-\mu 1$ aliquot of the diluted sample was applied to the column. The glyco and nonglyco protein fraction was eluted in the same way as mentioned under glyco $\mathrm{Hb}$. One hundred $\mu \mathrm{l}$ of each fraction were mixed separately with $4 \mathrm{ml}$ of diluted protein reagent (Isolab, Inc.). Colors developed were read at $595 \mathrm{~nm}$. The percentage of glycoprotein was calculated from these readings.
Ion exchange chromatographic quantitation of $\mathrm{Hb} A_{\mathrm{I}}$ in maternal blood. Microcolumns (Fast Hemoglobin Test System from Isolab, Inc.) prepacked with Bio-Rex 70 (IRC-50) cation exchange resin and reagents of the same company were used. The procedure supplied by the company was followed precisely. Fifty $\mu \mathrm{l}$ of blood were lysed with $200 \mu \mathrm{l}$ of the sample preparation reagent and $50 \mu \mathrm{l}$ of the lysate were applied to the column. Fast hemoglobin $\left(\mathrm{Hb} \mathrm{A}_{1}\right)$ fraction was eluted first with Solution 1 while the other hemoglobin fraction was eluted with Solution 2. The absorbance of each fraction was read at $415 \mathrm{~nm}$ in a Beckman spectrophotometer. The percentage of $\mathrm{Hb} \mathrm{A}_{\mathrm{I}}$ was calculated from these readings.

\section{RESULTS}

The results were analyzed by a standard computer program. The statistical tests performed are one-way analysis of variance (Bartlett's test), and paired analysis between the mothers and their newborns. Table 1 shows that the percentages of glyco $\mathrm{Hb}$ $(6.2 \pm 0.7 \%)$ of cord blood samples in eight newborns of IDDM mothers were significantly higher than in the normal group (4.7 $\pm 0.7 \%)(P<0.005)$. The glycoprotein levels of the plasma also showed significant increase $(P<0.005)$. Cord blood samples from White's Class A diabetic women, however, showed no significant difference from the normal group. The percentage of glyco $\mathrm{Hb}$ of IDDM mothers (maternal blood) was significantly higher than in the normal group $(P<0.005)$, while the increases in the level of fast hemoglobin $\left(\mathrm{Hb} \mathrm{A}_{1}\right)$ and glycoprotein were nonsignificant. The results of these parameters in the maternal blood samples of White's Class A diabetic women were not different from the normal group (Table 2). Paired analysis between the mothers and their own newborns revealed no correlation for glyco $\mathrm{Hb}$ and glycoprotein in the normal group $(\gamma=$ 0.08 ), whereas marginal correlations were observed in IDDM and White's Class A diabetic groups $(\gamma=0.37-0.42)$.

\section{DISCUSSION}

This work is a logical extension of a previously reported study, where an elevated $\mathrm{Hb} \mathrm{F}_{\mathrm{Ic}}$ (determined by ion exchange chromatography) was observed in the newborns of mothers with IDDM (12). At that time, it was not clear if this increase was due to an increase in the glycosylated or acetylated portion of $\mathrm{Hb}_{\mathrm{Ic}}$. In addition, the total glyco $\mathrm{Hb}$ including $\mathrm{Hb}$ glycosylated at sites other than the $\gamma$ chain amino terminus could not be determined by the ion exchange chromatographic technique. Utilizing glycoaffinity technique, this work confirms that glyco $\mathrm{Hb}$ and glycoproteins of the plasma are significantly elevated in the newborns of insulin-dependent diabetic mothers. Since glycoprotein and glyco $\mathrm{Hb}$ levels reflect the time-averaged blood glucose concentration in the preceding 2 to 3 weeks or months, these results may indicate that the fetuses of IDDM mothers had mean blood sugar values higher than fetuses of normal mothers. On the basis of the glyco $\mathrm{Hb}(6.4 \%)$ and $\mathrm{Hb} \mathrm{A}_{1}(7.1 \%)$ levels, White's Class A diabetics must have been well controlled which explains

\begin{tabular}{|c|c|c|}
\hline Samples* & $\begin{array}{c}\text { Red blood cell } \\
\text { glycohemoglobin } \dagger \\
(\%)\end{array}$ & $\begin{array}{c}\text { Plasma } \\
\text { glycoprotein } \dagger \\
\text { (\%) }\end{array}$ \\
\hline Normal group (20) & $\begin{array}{r}4.7 \pm 0.7 \\
(3.3-5.8)\end{array}$ & $\begin{array}{l}8.8 \pm 1.6 \\
(6.4-12.8)\end{array}$ \\
\hline $\begin{array}{l}\text { Newborns of White's Class A di- } \\
\text { abetic mothers (20) }\end{array}$ & $\begin{array}{r}4.4 \pm 1.2 \\
(3-7.6)\end{array}$ & $\begin{array}{l}9.0 \pm 1.9 \\
(6.1-11.7)\end{array}$ \\
\hline $\begin{array}{l}\text { Newborns of insulin-dependent } \\
\text { diabetic mothers (8) }\end{array}$ & $\begin{array}{l}(6.2 \pm 0.7) \ddagger \\
(4.9-6.8)\end{array}$ & $\begin{array}{c}(13.4 \pm 3.7) \ddagger \\
(10.0-19.1)\end{array}$ \\
\hline
\end{tabular}

* Number of samples analyzed is in parentheses.

$\dagger$ Mean $\pm \mathrm{SD}$, with range in parentheses.

$\ddagger$ Bartlett's test; $P<0.005$. 
Table 2. Percentages of glycohemoglobin, fast hemoglobin $(\mathrm{Hb}$ $A_{\mathrm{I}}$ ), and glycoprotein in maternal blood of different groups of patients studied

\begin{tabular}{|c|c|c|c|}
\hline Samples* & $\begin{array}{c}\text { Red blood cell } \\
\text { glycohemoglobin } \dagger \\
(\%)\end{array}$ & $\begin{array}{l}\mathrm{Hb} \mathrm{A}_{\mathrm{I}} \dagger \\
(\%)\end{array}$ & $\begin{array}{c}\text { Plasma } \\
\text { glycoprotein } \dagger \\
(\%)\end{array}$ \\
\hline Normal group (20) & $\begin{array}{c}7 \pm 0.6 \\
(5.9-8)\end{array}$ & $\begin{array}{c}7.4 \pm 0.9 \\
(6.1-8.9)\end{array}$ & $\begin{array}{l}12.8 \pm 1.4 \\
(10.0-15.4)\end{array}$ \\
\hline $\begin{array}{l}\text { White's Class A di- } \\
\text { abetic mothers } \\
\text { (20) }\end{array}$ & $\begin{array}{c}6.4 \pm 1.2 \\
(4.8-8.4)\end{array}$ & $\begin{array}{c}7.10 \pm 0.7 \\
(5.9-8.3)\end{array}$ & $\begin{array}{c}10.8 \pm 2.5 \\
(4.6-15.9)\end{array}$ \\
\hline $\begin{array}{l}\text { Insulin-dependent } \\
\text { diabetic mothers } \\
\text { (8) }\end{array}$ & $\begin{array}{c}8.9 \pm 0.9 \ddagger \\
(7.6-9.7)\end{array}$ & $\begin{array}{l}8.1 \pm 1.6 \\
(5.5-9.6)\end{array}$ & $\begin{array}{c}14.3 \pm 3.9 \\
(8.6-19.4)\end{array}$ \\
\hline
\end{tabular}

* Number of samples analyzed is in parentheses.

$\dagger$ Mean $\pm \mathrm{SD}$, with range in parentheses.

$\ddagger$ Bartlett's test; $p<0.005$.

why the glyco $\mathrm{Hb}$ and glycoproteins of their newborns were not different from the newborns of normal mothers. In this report, we were able to compare glyco $\mathrm{Hb}$ values in the newborns with the values of their own mothers. They were lower in the newborns $(4.7 \pm 0.7$ versus $7.0 \pm 0.6 \%)$ confirming previous findings (4). The decreased glyco $\mathrm{Hb}$ levels in the newborns may be due to a decrease for both red cells survival (21) and average blood sugar level in fetuses compared to adults. Another possibility is that $\mathrm{Hb} \mathrm{F}$ is glycosylated less readily than $\mathrm{Hb} \mathrm{A}$. However, the results of previous in vitro glycosylation studies (6) and normal levels of glyco $\mathrm{Hb}$ reported earlier in a homozygote for hereditary persistence of fetal hemoglobin condition do not confirm this (4). It is also noteworthy that even the plasma glycoprotein levels were significantly lower in the normal newborns than in their mothers. However, such a difference was not seen in the newborns of mothers with IDDM.

Current techniques for measurement of the relative concentration of glyco $\mathrm{Hb}$ fall under various categories such as ion exchange chromatography, electrophoresis, isoelectric focusing, and immunological and chemical analyses. Considering first the last category, the fluorometric technique has been considered an efficient means of determining the true number of total glyco groups (13). Second, the thiobarbituric acid assay is believed to provide a reasonable estimation of the protein-bound ketoamine (26). However, these procedures are very time-consuming. Ion exchange chromatography is subjected to interferences by temperature variations and the presence of $\mathrm{Hb} \mathrm{F}$, abnormal Hbs, and the labile aldimine (Schiff base). However, affinity chromatography is not influenced by such interferences (4). Moreover, comparison of the glyco $\mathrm{Hb}$ results obtained by affinity chromatographic technique with those of chemical methods resulted in a good correlation (5). In addition, the inter- and intra-assay coefficients of variation for glyco $\mathrm{Hb}$ as determined in earlier studies $(4,5)$ and for glycoprotein determined during this study was very satisfactory $(<5 \%)$.

Fetal macrosomia in diabetic pregnancies has been attributed to fetal hyperglycemia that is secondary to maternal hyperglycemia and consequent fetal hyperinsulinemia (Pederson theory). Direct evidence for this has been lacking since it is not possible to determine fetal blood glucose during pregnancy. Glyco $\mathrm{Hb}$ levels in cord blood may reflect the average levels of fetal blood glucose during the third trimester of pregnancy. Plasma glycoprotein level on the other hand may reflect the mean blood glucose level during the last few weeks of pregnancy. This is due to relatively high turnover of albumin which has a half-life in plasma of about 17 days (18). The results of this study indicate the presence of higher than average fetal blood glucose levels in insulin-dependent diabetic pregnancies. This presents further support to the Pederson theory (22).

\section{REFERENCES AND NOTES}

1. Abraham EC 1981 Glycosylated minor components of human fetal hemoglobin: chromatographic separation, identification and functional characterization. Biochim Biophys Acta 677:168

2. Abraham EC, Cope ND, Braziel NN 1979 On the chromatographic heterogeneity of human fetal hemoglobin. Biochim Biophys Acta 577:159

3. Abraham EC, Huff TA, Cope ND, Wilson JB, Bransome ED, Huisman THJ 1978 Determination of glycosylated hemoglobins $\left(\mathrm{Hb} \mathrm{A}_{1}\right)$ with a new microcolumn procedure: suitability of the technique for assessing the clinical management of diabetes mellitus. Diabetes 27:931

4. Abraham EC, Perry RE, Stallings 1982 Application of affinity chromatography for separation and quantitation of glycosylated Hb. J Lab Clin Med 102:187

5. Abraham EC, Stallings M, Abraham A, Elseweidy MM 1983 Affinity chromatographic quantitation of glycosylated hemoglobin in newborn infants. Hemoglobin 7:449

6. Abraham EC, Stallings M, Cameron BF, Huisman THJ 1980 Minor hemoglobins in sickle cell heterozygotes and homozygotes with and without diabetes. Biochim Biophys Acta 625:109

7. Allen DW, Schroeder WA, Balog J 1958 Observations on the chromatographic heterogeneity of normal adult and fetal human hemoglobin: a study of the effects of crystallization and chromatography on the heterogeneity and isoleucine content. J Am Chem Soc 80:1628

8. Bunn HF, Haney DN, Kamino S, Gabbay KH, Gallop PM 1976 The biosynthesis of human hemoglobin $A_{\mathrm{Ic}}$. J Clin Invest 57:1652

9. Bunn HF, Gabbay KH, Gallop PM 1978 The glycosylation of hemoglobin. Relevance to diabetes mellitus. Science 200:21

10. Fadel HE, Hammond SD 1982 Diabetes mellitus and pregnancy: management and results. J Reprod Med 27:56

11. Fadel HE, Hammond SD, Huff TA, Harp RJ 1979 Glycosylated Hb in normal pregnancy and gestational diabetes mellitus. Obstet Gynecol 54:322

12. Fadel HE, Reynolds A, Stallings M, Abraham EC 1981 Minor (glycosylated) hemoglobins in cord blood of infants of normal and diabetic mothers. Am J Obstet Gynecol 139:397

13. Gallop PM, Fluckiger R, Hannecken A, Mininsohn MM, Gabbay KH 1981 Chemical quantitation of hemoglobin glycosylation: fluorometric detection of formaldehyde released upon periodate oxidation of glycoglobin. Anal Biochem 117:427

14. Goldstein DE, Walker B, Rawlings SS 1980 Hemoglobin $A_{I c}$ in children and adolescents with diabetes mellitus. Diabetes Care 3:503

15. Gonen B, Rubenstein AH 1978 Hemoglobin $A_{1}$ and diabetes mellitus. Diabetologia 15:1

16. Gonen B, Rubenstein H, Rochman H, Tanega PS, Horwitz L 1977 Hemoglobin $\mathrm{A}_{1}$ : an indicator of the metabolic control of diabetic patients. Lancet 2:734

17. Huisman THJ, Meyerling CA 1960 Studies on the heterogeneity of hemoglobin I. The heterogeneity of different human hemoglobin types in carboxymethylcellulose and in Amberlite IRC-50 chromatography. Qualitative aspects. Clin Chem Acta 5:103

18. Kaplan A, Szabo LL 1983 Proteins in body fluids. In: Clinical Chemistry Interpretation and Techniques, 2nd ed. Lea \& Febiger, Philadelphia, p 150

19. McDonald M, Shapiro R, Bleichman M, Soloway J, Bunn HF 1978 Glycosylated minor components of human adult hemoglobin. J Biol Chem 253:2327

20. Paulsen EP 1973 Hemoglobin $A_{\text {Ic }}$ in childhood diabetes. Metabolism $22: 269$

21. Pearson HA 1967 Life span of the fetal red blood cell. J Pediatr 70:166

22. Pedersen J 1977 The Pregnant Diabetic and Her Newborn, 2nd ed. Williams \& Wilkins Co, Baltimore, p 211

23. Schneck AG, Schroeder WA 1961 The relation between the minor components of whole normal human adult $\mathrm{Hb}$ as isolated by chromatography and starch block electrophoresis. J Am Chem Soc 83:1472

24. Schwartz HC, King KC, Schwartz XX 1976 Effect of pregnancy on hemoglobin $\mathrm{A}_{\mathrm{lc}}$ in normal, gestational diabetes and diabetic women. Diabetes 25:1118

25. Shapiro R, McManus MJ, Zalut C, Bunn HF 1980 Sites of nonenzymatic glycosylation of human hemoglobin A. J Biol Chem 225:3120

26. Standefer JC, Phillip-Eaton R 1983 Evaluation of a colorimetric method for determination of glycosylated hemoglobin. Clin Chem 29:135

27. Weith H, Weibers J, Gilham P 1970 Synthesis of cellulose derivatives containing the dihydroxyboryl group and a study of their capacity to form specific complexes with sugars and nucleic acid components. Biochemistry 9:4396

28. This work was supported by National Institutes of Health Grant AM-32957. This is Contribution No. 0777 from the Department of Cell and Molecular Biology, Medical College of Georgia.

29. Address reprint requests to Dr. E. C. Abraham, Department of Cell and Molecular Biology, Medical College of Georgia, Augusta, GA 30912.

30. Received for publication October 4, 1983. 